\title{
What's going on?
}

\section{GLOBAL FASHION 2018}

ORGANISERS

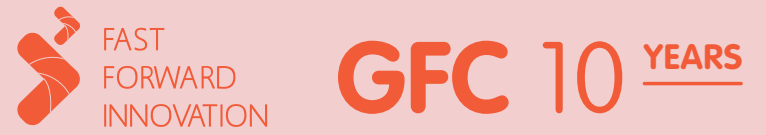
Ual: london college centre for
sustainable fashion Ten years of $\left.\right|_{\mathrm{I}} \mathrm{CSF}$ PONSORS

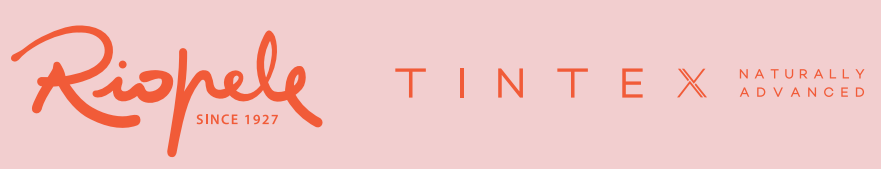

PAPTNERS a discourse on fashion, design and sustainability 


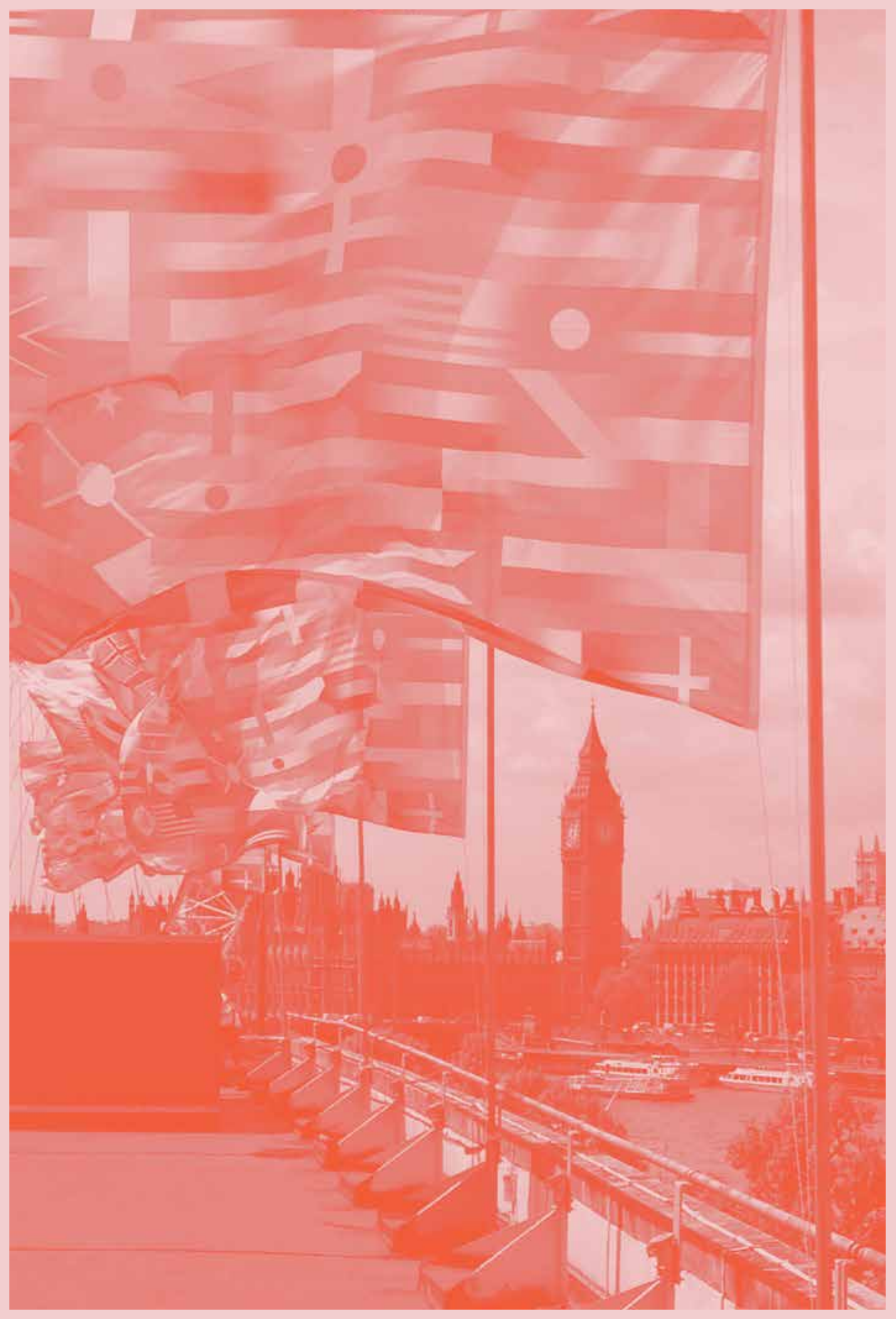

o8

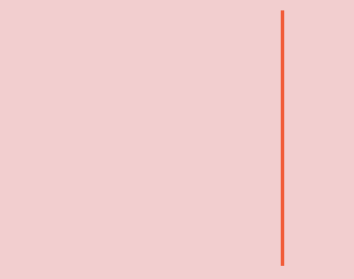

\section{Welcome}

The Centre for Sustainable Fashion and the Global Fashion Conference are delighted that you are joining us at 'What's Going On? A Discourse on Fashion, Design and Sustainability.'

Through two days of listening, discussing, watching and debating, we aim to explore the dynamics, challenges and propositions of fashion and sustainability through a design lens. The diversity of our assembled perspectives promises an exciting exploration, through the guiding themes of Power, Nature, Culture and Society.

When Centre for Sustainable Fashion set out in 2008, we convened fashion system actors together to co-sense what was happening and what needed to be done. A gap in fashion and sustainability research, education and industry practice became clear. In 2018, as we mark ten years of Centre for Sustainable Fashion, we join forces with the GFC project - also centered in sustainability and commemorating its ten years of existence - and we are very honoured to have your voices with us in London to recognise distinctive new knowledge and practice, challenge contemporary cultures and practices, and to propose how fashion can help us design, to live better, together, in harmony with nature.

Professor Dilys Williams

Professor Isabel Cantista

Director, Centre for Sustainable Fashion

ounder GFC-Global Fashion Conference

I8 


\section{About Centre for Sustainable Fashion}

Centre for Sustainable Fashion (CSF) is a University of the Arts (UAL) research centre based at London College of Fashion. It explores fashion's relational ecological, social, economic and cultural elements to contribute to sustainability in and through its artistic, business and educational practices.

\section{About Global Fashion Conference}

The Global Fashion Conference is a project that aims to bring together, on an international basis, academia and the fashion filiere contributing in an active way to the building of knowledge, the sharing of positive experiences with the aim of promoting a sustainable model of development.

This conference is organised on a bi-annual basis in collaboration with a university that carries out research on fashion studies. This project started in 2008 and is now celebrating its tenth anniversary. In 2018 it is in its 6th edition.

\section{Speakers and Contributors}

Claire Bergkamp / GLOBAL DIRECTOR OF SUSTAINABILITY \& INNOVATION, STELLA McCARTNEY

Sandy Black / PROFESSOR OF FASHION AND TEXTILE DESIGN AND TECHNOLOGY, CENTRE FOR SUSTAINABLE FASHION, LONDON COLLEGE OF FASHION

Otto von Busch / ASSOCIATE PROFESSOR OF INTEGRATED DESIGN, PARSONS NEW SCHOOL OF DESIGN

Orsola de Castro / CO-FOUNDER, FASHION REVOLUTION

Frances Corner / PROFESSOR OF ART AND DESIGN EDUCATION, HEAD OF LONDON COLLEGE OF FASHION; PRO-VICE CHANCELLOR, UNIVERSITY OF THE ARTS LONDON

Mary Creagh / MEMBER OF UK PARLIAMENT

Helen Crowley / HEAD OF SUSTAINABLE SOURCING INNOVATION, KERING

Heta Dobrowolski / CO-FOUNDER, RAW POWER MOVEMENT

Edwina Ehrman / SENIOR EXHIBITION CURATOR, CURATOR OF FASHIONED FROM NATURE, VICTORIA \& ALBERT MUSEUM

Kate Fletcher / PROFESSOR OF SUSTAINABILITY, DESIGN, FASHION, CENTRE FOR SUSTAINABLE FASHION, LONDON COLLEGE OF FASHION

Lynda Grose / ASSOCIATE PROFESSOR, CHAIR OF THE FASHION PROGRAM, CALIFORNIA COLLEGE OF THE ARTS Katharine Hamnett / FASHION DESIGNER

Angela McRobbie / PROFESSOR OF COMMUNICATIONS, GOLDSMITHS UNIVERSITY OF LONDON

Praveen Nahar / SENIOR FACULTY MEMBER IN INDUSTRIAL DESIGN, NATIONAL INSTITUTE OF DESIGN - INDIA

Deepa Patel / CREATIVE FACILITATOR

Sophie Slater / DIRECTOR, BIRDSONG

Stephen Sterling / EMERITUS PROFESSOR, UNIVERSITY OF PLYMOUTH

Dana Thomas / FASHION AND CULTURE JOURNALIST

Harold Tillman / CBE / FASHION RETAILER ENTREPRENEUR AND FORMER CHAIR OF BRITISH FASHION COUNCIL

Dilys Williams / PROFESSOR OF FASHION DESIGN FOR SUSTAINABILITY, DIRECTOR OF CENTRE FOR SUSTAINABLE FASHION

Lola Young / OBE/ BARONESS YOUNG OF HORNSEY

Ania Zoltkowski / DESIGNER AND MA FASHION FUTURES ALUMNI, LONDON COLLEGE OF FASHION 


\section{nature \& culture}

We will explore agendas such as, but not limited to, fashion learning from nature, fashion and human nature, fashion systems for sustainability \& fashion habits and habitats. We will reference fashion's social practice, fashion making and meaning, cultures of care \& fashion's identity, stories and rituals.

\section{power \& society}

This session will explore agendas such as, but not limited to, fashion design for democracy, fashion business practices for better buying, fashion education for equality, fashion as activism, fashion and politics. We will reference migration and conflict, fashion design for sustainability strategies and sustainable prosperity.
RHS East and Centre Auditorium

8.30am REGISTRATION - TEA AND COFFEE

9.30am WELCOME / DILYS WILLIAMS _ Professor Fashion Design for Sustainability, Centre for Sustainable Fashion, featuring a

musical performance by HEIDI VOGEL

9.45am OPENING / MARY CREAGH MP _ Member of UK Parliament

9:55 - 11:00am SPEAKERS / KATE FLETCHER _ Professor of Sustainability, Design, Fashion, Centre for Sustainable

Fashion \& HELEN CROWLEY_ Head of Sustainable Sourcing Innovation, Kering / CHAIR_ DILYS WILLIAMS

$11.00-11.20 \mathrm{am}$ BREAK

11.20 - 12.00pm IN CONVERSATION / KATHARINE HAMNETT _Fashion Designer WITH DANA THOMAS _Fashion and Culture journalist

$12.00-1.00 \mathrm{pm}$ LUNCH

Various Rooms

1.00- 2.35pm PARALLEL SESSIONS S01-S06

$2.35 \mathrm{pm}-2.45 \mathrm{pm}$ BREAK

2.45 - 4.20pm PARALLEL SESSIONS S07-S12

4.20 - 4.30pm BREAK

RHS East and Centre Auditorium

4.30 - 6.00pm SPEAKERS / STEPHEN STERLING _ Emeritus Professor, University of Plymouth, EDWINA EHRMAN _ Senior Exhibition Curator, Victoria \& Albert Museum, PRAVEEN NAHAR _ Senior Faculty Member in Industrial Design, National Institute of Design - India / CHAR_ DEEPA PATEL

7.30pm GALA RECEPTION (by invitation only) _ House of St Barnabas (Soho)
RHS East and Centre Auditorium

9.00am TEA AND COFFEE ON ARRIVAL

9.30am DAY TWO OPENING / DILYS WILLIAMS _ Professor Fashion Design for Sustainability, Centre for Sustainable Fashion

9.35am WELCOME / ISABEL CANTISTA Global Fashion Conference \& DAMIEN DELILLE Invitation to GFC2020 University of Lyon

9:45 - 10:45am SPEAKERS / OTTO VON BUSCH _ Associate Professor of Integrated Design, Parsons New School of Design AND

LYNDA GROSE Associate Professor, California College of the Arts / CHAIR DILYS WILLLAMS

10:45 - 11:05am BREAK

11.05 - 12:00pm PANEL DISCUSSION / SOPHIE SLATER _ Brand Director, Birdsong, CLAIRE BERGKAMP _ Global Director of Sustainability \& Innovation, Stella McCartney, ORSOLA DE CASTRO Founder and Creative Director, Fashion Revolution \& HETA DOBROWOLSKI _ Co-Founder, Raw Power Movement / CHAIR _ SANDY BLACK _ Professor of Fashion and Textile Design and Technology, Centre for Sustainable Fashion

$12.00-1.00 \mathrm{pm}$ LUNCH

Various Rooms

$1.0-2.35 \mathrm{pm}$ PARALLEL SESSIONS S13-S18

2.35- 2.45pm BREAK

2.45 - 4.20pm PARALLEL SESSIONS S19-S24

4.20 - 4.30pm BREAK

RHS East and Centre Auditorium

4.30 - 4.40pm REFLECTIONS FROM HAROLD TILLMAN CBE Fashion Retailer Entrepreneur

4.40 - 5.40pm IN CONVERSATION / FRANCES CORNER _ Head of London College of Fashion, Pro-Vice Chancellor of University of the Arts London, LOLA YOUNG OBE Baroness Young of Hornsey AND ANIA ZOLTKOWSKI Designer and London College of Fashion Alumna / CHAIR_ANGELA MCROBBIE_ Professor of Communications, Goldsmiths University of London 5.40 - 6.00pm CONFERENCE CLOSING REMARKS / DILYS WILLIAMS 


\section{Parallel sessions}

$1.00-2.35 \mathrm{pm}$

SOI RHS east and centre auditorium / Cullture: Global Perspectives char _ Kelly dearsley

RP120 Empowering Indigenous Mexican Groups Through Fostering the Practice of Traditional Textile Craffts

- ENDO PORTLLO HOSHIAKARI/ Ryerson University, Canado

RP10 Consumers' intentions towards sustainability: an analysis of the Spanish fass fashion industry _ BETHAN ALEXANDER / London College of Fashion, UK

RP150 Creative dynamics: Ethical textile entrepreneurship and respectful design in the Peruvian context

- RAISA FERRER PIZARRO / Pontificia Universidad Católica del Perú, Peru

RP 77 The Meeting Point of Global and Local Slow Fashion Practices - Case Studies: Locus Artis and Full Circle

- IVANA CULAK AND LEA VENE / CIMO - Center for Research of Fashion and Clothing-University of Zagreb, Croatio

Photo7 Paradox of opportunity: a Comparative Perspective _ NEHA DIMRI/ Pearl Academy, India

SO2 room 105 /Society: Speed and Pace chair_anna Fitzpatrick

RP70 Slow + Fashion: Revisited_ _ HAZEL CLARR/ Parsons New School, USA

RPP108 Slow Fashion + Retail Design: Designing experiences to influence sustainable consumers behaviors _ REBEKAH MATHENY / The Ohio State University, USA

$\mathrm{RP}_{107}$ Japanese Fashion and the Luxury of Slowness _ TOB Y SLADE/ Bunka Gakuen University,Japa

RP20 Fashion, Identity and Stories Told _ MARLLYTN DELONG AND CAREN S. OBERG/University of Minnesota, USA

RP76 How to improve the fashion reputation? The role of sustainability _ TERESA SADABA AND PAULA GARGOLES / ISEM Fashion Business School, Spain -

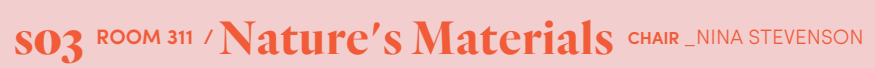

RPPo6 Borrowed Cloth: a holistic research and design intervention for sustainable fashion _ KRRTEN SCOTT / stituto Marangoni, UK

RPII Entanglements of the Body and Fungi in Experimental Fashion _ ALLA PARKER / UNSW Ar \& \& Design, Sydney, Australia

$\mathrm{RP}_{4} 6$ Multi-stakeholder perspectives for scaling up fashion upcycling businesses in the UK _ KYUNGEUN SUNG / De Montfort University, UK

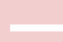

SO4 ${ }^{\text {ROOM } 415}$ / Power, Care and Places chair_francesco mazzarelaA

RP 153 Residencies: mixed methods design research investigating fashion through place _ KATELIN TOTH-FEELL L London College of Fashion, UK

RP195 Climate Positive Fashion Futures: Sustainability Upgraded _ D DAN-EN LIN / London College of Fashion, UK

RP209 One Dress: Shaping fashion futures through utopian thinking _ MLLA BURCIKOVA / London College of Fashion, UK

$\mathrm{RP}_{73}$ Designning for future adults: what's going on in contemporary children's fashion? _ AUDE LE GUENNEC / Heriot Watt University, UK

SO5 ROOM 418 / Ed Uication CHAR_JULA CREW

$\mathrm{RP}_{24}$ Design for sustainability - exploring students' translations from brief to prototypes _ ULLA RAEBILD AND VBEEKE RIIBEERG / Design School Kolding, Denmark $\mathrm{RP}_{31}$ V Visualising Fashion Studies: Research-based Teaching and Learning in Fashion Design Education _ JURE PURGA/ / University of Teacher Education of Vienna, Austria RP18I Trends Forecasting as a tool for Sustainable mind-sets in Fashion Education _CAROLINE RAYBOULD / Birmingham City University, UK $\mathrm{RP}_{35}$ Establishing foundations towards clothing long
- ANA CONNOR-CRABB / Leeds Beckett University UK/USA

RPF The Wheel: A teaching tool for fashion design students _ DESIREE SMAL / Faculty of Art, Design and Architiecture - University of Johannesburg, South Africa

so6 room 511 / Workshops: Power / seepagen

I:00 - 1:45pm Which of these two tee-shirts would you buy? _ AURORA PALLARD / London College of Fashion, UK

1:50-2:35pm Invent your own Fashion Economy; Sustainability in a Post-Consumer Utopia _ RACHAEL TAYLOR / Southampton Solent University, UK

\section{$2.45-4.20 \mathrm{pm}$}

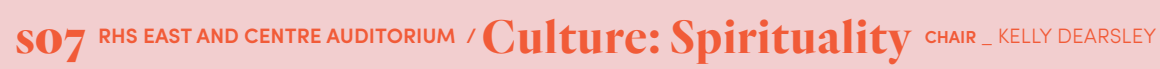

$\mathrm{RP}_{207}$ Can infusing spiritual principles and practices into the fashion design field, create a more sustainable industry?

RP161 Spirituality, Integral Yoga and Integral Business: A Case Study of Upasana, Aurroville _ GOUTAM SAHA / National Institute of Fastion Technology, India

RP81 Faith in Design: a human right, missed markets and as design activism _ SUE THOMAS / Heriot Watt University, UK

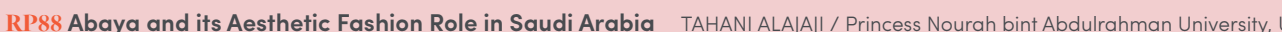

$\sqrt{10}$

SO8 Room 105 / Open Theme chair_Rosemary VArley

RP16 Could creative design break through the bottlenecks of development in knitwear brands? _ XIN ZHANG / Birmingham City University, UK

RPII3 Fashion branded eyewear: brand licensing and the perception of fashion conscious consumers _ ALEEN STEWART / Glasgow Caledonian University, UK

RP217 Dress, shoes and heeled prosthetic legs: the Paralympic bid to break fashion barriers _ SARA CAVAGNERO / Italian Red Cross, Italy AND DOMENICO DEMARINIS , UNIIT-Roma, Haly

RP60 Creative and effective communication trends among fashion brands: Contagious magazine analysis 2010-2017

_ MARTA TORREGROSA / University of Navarra, Spain

Testim6 Valérius 360: Co-creating a circular fashion system _ DOLORES GOUVEIA AND MIGUEL COSTA I Valérius - Têxteis SA, Portugal

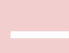

SO9 ROOM 311 / Nature's Materials CHAR_ NINA STEVENSON

$\mathrm{RP}_{44}$ L Living dresses: about synergies, autopoiesis and seamstress bacteria _ HELENA FERNANDEZ NÓVOA / Universided de Vigo, Spain

RP7 Dynamics of natural dyeing in fashion. Two cases _ PETRA HOLMEERG / The National Museum of World Culture, Swede

$\mathrm{RP}_{124}$ Batik Pattern Design and Development Inspired by Fowers in The Story of Phra Abhai Mani, Thai Literat

- CHANATHINAT CHAYYAPOO/ Phuker Rajabnat University, Thailand

KR

RP210 Parivartan: Crafting tassels to re-invent garment making _ ASHISH DHAKA / Pear I Academy, India

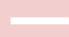

SiO Room 415 / Power: Co-operation char _ Fancesco mazzarella

RP91 Co-Design of Designers and Craftsman and the Communication of this Partnership - a reflection _ ANA BROEGA / University of Minho, Portuga RPHo Connecting through THREADs: Investigating Individual Identity and Integration through Textiles

- JANE MALCOLM-DAVES U University of Copenhagen AND ELLE SKJ OLD / Design School Kolding, Denmark

政

RP182 WEAR Sustain Network: Ethical and Sustainable Technology Innovation in Wearables and Etextiles _ RACHEL LASEBBKAN / Queen Mary University of London, UK

0

SII ROOM 418 / Education CHAR_ JULA CREW

$\mathrm{RP}_{52}$ Fashion education between heritage and research futures_ BRITTA KALRREUTER / Heriot Watt University, UK

RPPII F Fashion Futures a Societal Sustainability, possible directions from scenario development _ WOUTER EGGINK / University of Twente, Netherlands

$\mathrm{RP}_{208}$ Collaboration for change - seeding the future within fashion education _ SANDY BLACK / London College of Fashion, UK

$\mathrm{RPP}_{173}$ Teaching for sustainable development: Designing a responsive business elective _ NATASCHA RADCLYFFE-THOMAS / London College of Fashion, UK

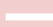

SI2 Rоoм 511 /Workshops: Nature/ssopagen

2:45-3:30pm How to Creatively Reuse Plastic Waste to Make New Products _ MARLLENA SIAMPTANI / London College of Fashion, UK

3:35- 4:20pm Companionship with Nature - a material dialogue _ KATHERINE POGSON / London College of Fashion, UK 


\section{Parallel sessions}

I.00-2.35 pm

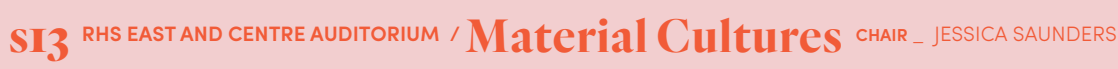

RP215 Sustaining the Gandhian Philosophy in Global Fashion for Improved Adaptability _ ANTA BORA / Pearl Academy, India

RP185 Future Of Indian Salwar: Resurgence of Gender Equality _ SHALIN BISHT / Pearl Academy, India

$\mathrm{RP}_{34}$ Favourite garment stories as a catalyss for care _ MONIKA HOLGAR / Queensland University of Technology, Australi

$\mathrm{RP}_{55}$ Emotionally durable fashion: Framing the creation of emotional value in fashion practices and discourses _ ALEX ESCULAPIO / University of Brighton, UK

0

SI4 Room 105 / Society and Conviviality chair_monicaвUChan-NG

RP28 Designing Garments with Evolving Aesthefics in Emergent Systems _ LYNDA GROSE AND TIMO RISSANEN / Parsons New School of Design, USA

RP221 Collaboration for sustainability: the key to "making it work" _ HANNAH PARRIS AND LAUREN NELLSON / Common Objective, UK

RP125 Connected Spacess: experimential and social busness practices or Here Today Here Tomorrow

- JULA CREW, KATELYN-TOTH FEELL AND ANNA-MARIA HESSE/ Here Today Here Tomorrow Design Collective, UK

$\mathrm{RP}_{45}$ Better Fashion Futures. Exploring Service Design to reimagine future fashion practices _ CLARE DENNINGTON / Oslo school of Architecture and Design, Norway

RP 127 Fashion as Your Ally: Analyzing Coverage on the Sartorial Choices of Politicians _ DIANA YCHU CAO / Parsons New School of Design, USA

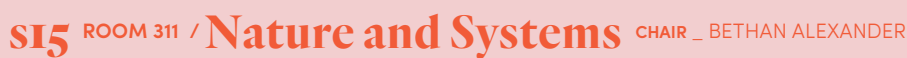

RP226 Interdisciplinary Life Cycle Thinking Tools; enabling collaboration for circular design _ KATE GOLDSWORTHY AND DAWN ELLAMS / Chelsea COllege of Arts, UK RPP8 8 Mixing It Up in Prato: identifying innovation hotspots whithin mechanical textiles recycling _ CATHRYN HALL/ Chelsea College of AArs, UK

$\mathrm{RP}_{17}$ The Textile Reuse Programme: Building macro sustainable systems for used clothing _ BERNADETTE CAEEY / The Formary, New Zedlan

RP63 Returned from Africa: design for upcycling second-hand clothes in Ghana _ ANTHONY KENT / Nottingham Tren
RP 49 The Tweed Run: the sustainable rise of fashionable cycling _ CATHERINE GLOVER / University of Northumbria, UK

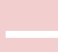

SI6 Room 415 / Power, Creativity and Democracy char_KATE FLetcher

RPIA A critical political economy of bohemian subjectification: internationalised education for transcultural labour
- RUPERT WALRRON / London College of Fashion, UK

$\mathrm{RP}_{13}$ Women Garment Workers' Struggle in a neo-colonial world _ TIBBE SMTHH LARSEN / Lund University, Denmark

RP III Mapping the politics of fashion _ ANNA FITZPATRICK / London College of Fashion, UK

RP222 Establishing total cost for apparel in responsible production conditions _MD REAUUL HASAN / North Carolina State University, USA

RP79 Democratizing Fashion Design Pedagogies: From Exclusion to Inclusion _ TANVEER AHMED / Open University, UK

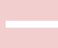

SI7 Room 418 / Film and Photo chair_ _amilla palestra

Fillm2 Unfolding: The hand of the cloth_ MIRANDA SMITHERAM / Auckland University of Technology, New Zealand

Fillm3 Speculating the future Haute Couture - Designing mass-customisable garments for the sustainable future

- KYE SHIMIZU AND KOTARO SANO / Keio University, Jpapan

Fillm4 Biological Tailor-Made - A study on 2.5 dimensional fashion pattern cutting as zero waste method_ K KAZUYA KAWASAKI / Keio University SFC, Japan

Fillm5 Speculative, Fashionable, Wearable - Engaging Fashion Design with Wearable Technology for the sustainable future _ DAJlRO
Photo3 The Afterlife of Discarded Woolens: Who is Recycling my Clothes? _ ANUPAM KAPOOR / National Institute of Fashion Technology, India

$$
\sqrt{2}
$$

SI8 Room 511 / Workshops: Society / seop page 12

I:00-1:45pm Whole Cloth Cutting _ GREGORY CLMER / Parsons School of Design, USA

1:50-2:35pm Introducing Sustainable Design Cards _ KAREN MARRE HASLING AND ULLA RAEBBLD / Design School Kolding, Denmark

\section{$2.45-4.20$ pin}

Sig rhs east and centre auditorium / Cullture: Counter Narratives char _ natascha radclyfe-thomass

RP199 Utility in Home Fashion Design: Considered Design for Sustainability _ MARYSSA COOK-OBREGON / London College of Fashion, UK

$\mathrm{RP}_{22} 4 \mathrm{Re}$-Fashioning the way we wear. Is there "'"'" in sustainable dressing? _ TAMZII ROLLASON / RMIT University, Australia

RP8 Of Stuff and Nonsense? Conflicting values in the retention of fashioned objects _ CAPE LOMAS / London College of Fashion.

$\mathrm{RP}_{144}$ The Human Condition of Dress - Homo laborans _ ISABELA GYGAX / London College of Fashion, UK

$\mathrm{RP}_{170}$ Closet Frugality: Reflexive Privation as Fashion(able) Identity _ KRIISTF AVRAMSSON / Carleton University, Conado

-

S20 ROOM 105 / Society and Systems Chair_ANARONCHA

RP 192 Going Local: Design and Sustainability in New York City's Garment Center _ TESSA MAFFUCCI / Pratt Institute (NY), USA

$\mathrm{RP}_{193}$ Barriers that hinder consumption of second-hand clothing - A socio cultural perspective _ CLARE DAWSON / Coventry University London, UK.

RP92 Second-hand Clothing Market: an alternative Sustainable Practice or another Fashion Trend? _ELENI BALTZOGLOU / Parsons School of Design, USA

RP 99 Transference of Textile Skill Knowledge in Rural-to-Urban Migration in the Bolivian Altiplano

- BEREAANARI AND KATALIN MEDVEDEV / University of Georgia, USA

政

S2I ROom 31 / Nature and Systems Char _ Bethan ALEXANDER

RPI26 SMART Cities and Waste Innovation _ GRAEME EVANS / London College of Fashion, UK

RP122 Teardown and Redesign: dis- and re-assembling textile blends in the circular economy _ LAETTTIA FORST / London College of Fashion, UK

RPIII Fashion and Interior Design: Transdisciplinary approach for fabric experiments and textile upcycling _ MÁRCIA BERGMANN / PUC - Rio de Janeiro, Brazil

$\mathrm{RP}_{163}$ Enrolling Stakeholders Within a Local and Convivial Narrative for Circular Fashion _ MARION REAL / Chelsea College of AArs, UX

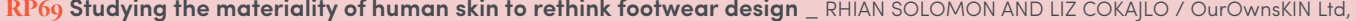

(1)

S22 ROom 415 / Power and Technology chair_ GABRELLE MILLR

$\mathrm{RP}_{205}$ Shaping Up a Sustainable Fashion Future in India- The Augmented Reality Way _ HARSHA RANI / National Institute of Fashion Technology, India

RP 179 Fashioning circular logic: addressing the viability of a closed-loop economy for fashion _ ANNE PERSSON-SMITH / City University of Hong Kong, Hong Kong

$\mathrm{RP}_{2}$ Could Tractability in the Luxury Jewelry Market Create an Emotional Added-Value? _ DANIELE KELLER AVIRAM

RP1333 Fashion Design Practices in Supply Chain for Sustainability _ MADALENA PERERRA / Universidade de Beira Interior, Portug

(a)

S23 ${ }^{\text {ROOM } 418 \text { / Open theme CHAR_ROSEMARY VARLEY }}$

RP6r Instagram communication strategies: a comparative analysis of fast fashion and luxury brands _ CRISTINA SANCHEZ-BLANCO / Universidad Navarra, Spain

$\mathrm{RP}_{23}$ How to Make Sustainable Fashion Cool? _ LYuBOV SACHKOVA, London College of Communication, UK

$\mathrm{RP}_{54}$ Identity of sustainable fashion brands at the stores _ EUGENIA JOSA / ISEM Fashion Business School, SPain

RP 59 Data Driven Digital Business Strategies: an analysis of the Spanish footwear _ PATRICIA SANMIIGUEL/ ISEM Fashion Business School, Spain

RP105 To be a gentlewoman: shifts in the representation of women of fashion _ DARAA MIKERINA / Charles University in Prague, Czech Republic

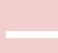

S24 ${ }^{\text {Room } 511 / \text { Workshops: Culture /sop pago } 12}$

2:45-3:30pm Elements of Quality: beyond seamlines and fabrics _ EMMA RIGBYY AND ANA CONOR-CRABB / London College of Fashion, UK

3:35 - 4:20pm What's Going On, In Fashion Activism? _ FRANCESCO MAZZARELLA AND HELEN STOREY / Centre for Sustainable Fashion, London College of Fashion, UK 


\section{Workshops}

\section{day I - $^{\text {sin ocrosere }}$}

day $2^{-1 \text { M NOVEMER }}$

1:00 - 1:45pm

Which of these two tee-shirts would you buy?

AURORA PAILLARD / UAL - London College of Fashion, UK

Sustainable Fashion consumer behaviour researchers are facing an issue while carrying out their research; i.e. most of their participants claim to prone and buy Sustainable Fashion, which is not the case in real life. Researchers need to better understand this issue in order to accurately assess and understand Sustainable Fashion consumer behaviour. The aim of this interactive session is to identify the biases in Sustainable Fashion consumer behaviour research.

\section{1:50-2:35pm}

Invent Your Own Fashion Economy; Sustainability in a Post-Consumer Utopia

RACHAEL TAYLOR / Southampton Solent University, UK

This workshop aims to use a co-creative and activist approach to disrupt current economic models, re-designing the fashion design process and creating sustainable interventions as practical outcomes. The focus of the workshop is to collaboratively re-evaluate how fashion can invent its own life cycles of economies, combining alternative movements within sustainable consumption, lifestyles and peer 2 peer networks.

\section{2:45 - 3:30pm}

How to creatively reuse plastic waste to make new products

MALA SIAMPTANI / UAL - London College of Fashion, UK

This workshop/demonstration will be an introduction into the process of converting household plastic waste, into a valuable material resource. Participants will gain a solid understanding of fundamental techniques that will empower them to make their own material. This includes learning the necessary steps of how to separate plastics, and how to form this material into a product, using hand-craft techniques or digital manufacturing techniques (CNC-milling).

\section{3:35-4:20pm}

Companionship with Nature - a material dialogue

KATHERINE POGSON / UAL - London College of Fashion, UK

The notion of a divide between humanity and the rest of 'nature' can be seen as a root cause of environmental degradation, bio abundance loss and extinction. Informed by contemporary ecological philosophy which questions human boundary constructs, this workshop seeks to test two speculative practices for reactivating engagement with the natural world, developed as part of the author's PhD research in the Centre for Sustainable Fashio

\section{1:00 - 1:45pm}

Whole Cloth Cutting - a technique for minimal waste designing

GREG CLIMER / Parsons School of Design, USA

Western tailoring layouts are not traditionally concerned with how many cuts are put into the fabric. Fabric is not viewed as sacred, something who's shape and size should be honoured. This workshop uses minimally cut sheets of paper as the starting point for designing garments. It explores the different forms generated by paper and fabric and capitalizes on these whole cloth as an object of beauty and aims to capitalize on it within the design process.

\section{1:50 - 2:35}

Introducing Sustainable Design Cards

KAREN MARIE HASLING \& ULLA RAEBILD / Design School Kolding, Denmark

The Sustainable Design Cards (2017) (www.sustainabledesigncards.dk) is a tangible tool for designers and design teachers to work with product longevity and circular thinking in their practice. They have been developed at Design School Kolding between 2015-2017 in two iterations, the first with an industry focus and the second with an educational based on previous research on design methods and sustainable design. In this workshop participants are introduced to the tool, sharing user experiences deriving from teachers, facilitators and learners in academia and industry, where after workshop participants will engage two and two with the cards.

2:45 - 3:30pm

Elements of quality: beyond seamlines and fabrics

EMMA RIGBY / UAL - London College of Fashion, UK \& ANJA CONNOR-CRABB / Leeds Beckett University, UK

This workshop is an enquiry into combined material and social construction of garment quality. Beyond a garment's seams and materials, it aims to explore how quality is understood through the everyday wear of clothing, from the perspective of the user. Expectations for garment quality have co-evolved over time alongside changes in the way clothing is produced, consumed and

\section{3:35- 4:20pm}

What's going on, in fashion activism?

FRANCESCO MAZZARELLA AND HELEN STOREY / UAL - London College of Fashion, UK

The mainstream ecosystem has proven unsustainable in terms of livelihood, cultural heritage, social equality, and environmental stewardship. This is building momentum for designers to create counter-narratives towards sustainability in fashion. However, there is the need to further investigate the roles, methods, and practices design activists enact in fashion activism.

With this in mind, a series of hands-on, participatory activities will be facilitated, engaging the workshop participants in mapping out the design activism landscape and explore the role of counter-narratives towards sustainability in fashion. The emergent field of fashion activism, aimed at making a positive impact in the world. 


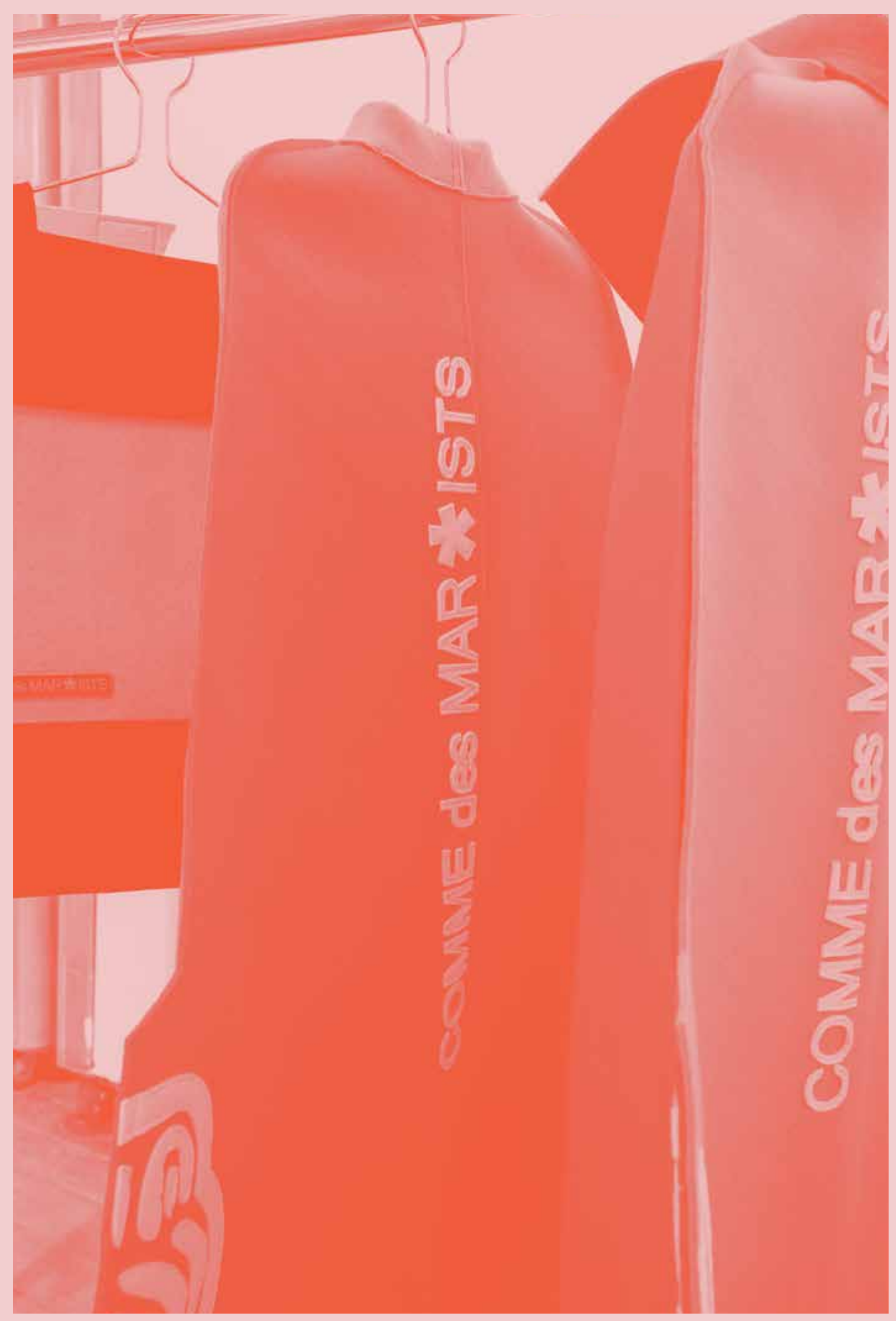

\section{RHS West Lounge Space}

Generously supported by JOHN LEWIS \& PARTNERS

Refreshments will be available all day in the RHS West space, as well as space to sit and relax. If your ticket includes lunch, then this can also be collected from the West Space during the lunch break.

ACTIVITIES IN THE WEST SPACE ARE PROGRAMMED BY CENTRE FOR SUSTAINABLE FASHION AND INCLUDE:

Design Your Own Economy: A Post-Capitalist Kitset / Interactive Digital Installation MONICA BUCHAN-NG

Tired of oppressive fashion systems? Disillusioned by destructive industries? Anxious about the future? Design Your Own Economy may be right for you.

This easy, step-by-step kitset unpacks the complexities of the 'economy' our society operates within - the systems by which humanity produces, distributes, and satisfies the requirements of human life. Users can create their own alternative, tailored to fit a personal fashion arcadia.

Towards a new framework for fashion / Discussion, Wednesday 31st October 2:45 - 4:20pm KATE FLETCHER AND LYNDA GROSE

Action needs to be taken to reduce demand for materials and cope with future environmental threats. In fashion, as in other sectors, such measures are challenging and uncomfortable for both the wearers of clothes and the billion-dollar industry that creates them.

the fashion sector and exciting visions for fashion based on fundamentally rethinking the whole system.

These include those which probe more deeply into the root causes of the problems we face, and with imagination, not fantasy, engage with the disruptive, complicated reality of the changing world.

\section{... And in the Fashion Space Gallery}

Comme des Marxists exhibition

Comme des Marxists, presented in the UK for the first time, continues Austrian-American artist Rainer Ganahl's long-term investigations into the relationships between daily life, culture, economic systems and political structures.

The exhibition forms part of the year-long celebration of the Centre for Sustainable Fashion's 10-year anniversary. Together with Fashion Space Gallery, CSF invited Ganahl to challenge our understanding of the fashion system, using his playful, humorous, yet thought-provoking approach.

The exhibition curator, CAMILLA PALESTRA, will be in the Fashion Space Gallery on Thursday 1st November between 12noon-1pm to provide insight and respond to any questions. 


\section{Delegates}

(a) AILEEN STEWART Glasgow Caledonian University / UK ALBERTINA REIS Riopele / Portugal ALEVTINA SCEPANOVA Vilnius College of Design / Lithuania ALEX ESCULAPIO University of Brighton / UK ALEX MCINTOSH London College of Fashion / UK ALEXANDER BARANOV Robinzon.ru, LLC / Russia ALIA PARKER UNSW Art \& Design / Australia ALISON ASHBY Plymouth University / UK AMANDA JOHNSTON The Sustainable Angle / UK AMY FOSTER-TAYLOR London College of Fashion / UK ANA CRISTINA BROEGA Universidade do Minho / Portugal ANGHARAD MCLAREN Nottingham Trent University / UK ANITA BORA Pearl Academy / India ANJA
CONNOR-CRABB Leeds Beckett University / UK/USA ANNA FITZPATRICK London College of Fashion / UK ANNA-MARIA HESSE Here Today Here To ANNE F. PIERSON-SMITH City University of Hong Kong / Hong Kong ANTHONY KENT Nottingham Trent University / UK ANUPAM KAPOOR National Institute of Fashion Technology / India ARIANA NICOLETTI VaA / UK ASHISH DHAKA Pearl Academy / India ASLANBEK SHOGENOV OOO Prestizh Plyus / Russia AUDE LE GUENNEC Heriot Watt University / UK AURORA PAILLARD London College of Fashion / UK (b) BARBARA BARABÁS London College of Fashion / UK BÁRBARA BORLIDO Tintex / Portugal BEREA ANTAKI University of Georgia / USA BERIT KONSTANTE NISSEN Copenhagen School of Design \& Technology / Denmark BERNADETTE CASEY

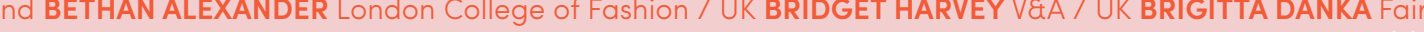
Wear Foundation / Netherlands BRITTA KALKREUTER Heriot Watt University / UK BRONWYN SEIER London College of Fashion / UK (C) CAMILLA PALESTRA London College of Fashion / UK CAREN OBERG University of Minnesota / USA CARLA BELLISIO Parsons School of Design / USA CARLOS COSTA I\&D Riopele / Portugal CAROLINE RAYBOULD Birmingham City University / UK CATHERINE GLOVER University of Northumbria / UK CATHRYN HALL Chelsea College of Arts / UK CHANATHINAT CHAIYAPOO Phuket Rajabhat University /
Thailand CHIARA COLOMBI Istituto Politecnico di Milano / Italy CHLOE VASTA London College of Fashion / UK CLAIRE DAWSON Coventry University London / UK CLAIRE DENNINGTON Oslo School of Architecture and Design / Norway CLAIRE WEISS London College of Fashion / UK CLARE LOMAS London College of Fashion / UK CLEMENS THORNQUIST Swedish School of Textiles / University of Boràs / Sweden CONNIE SVENDSEN Copenhagen School of Design \& Technology / Denmark CRISTINA SANCHEZ BLANCO Université de Lyon / France DANIELLE KELLER AVIRAM AMD - Akademie Mode \& Design / Germany DARIA MIIKERINA Charles University / Czech Republic DARIYA GILEVA International HR Agency "Kontakt" / Russia DARIYA TULUBENSKAYA International HR Agency "Kontakt" / Russia DAVID ZAJTMANN Institut Français de la Mode / France DAWN ELLAMS London College of Fashion / UK DEAN RICKETTS The Watchman Agency / UK DESIREE SMAL University of Johannesburg / South Africa DIANA YICHU CAO Parsons School of Design / USA DIAN-JEN LIN London College of Fashion / UK DIOGO MENDES PINTO Fast Forward Innovation / Portugal DOLORES GOUVEIA Valerius - Texxeis SA DOMENICO DEMARINIS Universitáa degli Studi Internazionali di Roma / Italy (e) EDITA

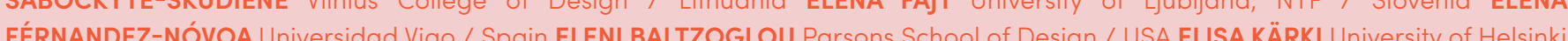
Fin E Z Finland ELIZABETH MCLAFFERTL London College of Fashion/ UK ELIZABETH PARKER LOndon College of Fashion/UK ELLLOT TODD Las Glasgow Caledonian University / UK EMMA RIGBY London College of Fashion / UK LUGENA JOSA ISEM / Spain EVA VON / UK FRANCESCO MAZZARELLA London College of Fashion / UK FRANCISCA OLIVEIRA Riopele / Portugal (g) GABRIELA MACHADO ANDRÉ Roupartilhei blog / Fashion Revolution / Brazil GABRIELLE MILLER London College of Fashion / UK GEORGINA NADAL -RODRIGUEZ Manchester Metropolitan University / UK GIGDEM GOGUS London College of Fashion / UK GOUTAM SAHA National Institute of Fashion Technology / India GRAEME EVANS London College of Fashion / UK GREGORY CLIMEr Parsons School of Design / USA (h) HANNAH PARRIS Common Objective / UK HARSHA RANI National Institute of Fashion Technology / India HAZEL CLARK Parsons School of Design / USA HEATHER PICKARD London College of Fashion / UK HELEN HILL Nottingham Trent University / UK HELEN STOREY London College of Fashion / UK HIKARI KATAOKA London College of Fashion / UK HOSHIAKARI ENDO PORTILLO Ryerson Unversity / Canada (i) ISABEL CANTISTA Fast Forward Innovation / Portugal ISABELA GYGAX London College of Fashion / University CULAK CIMO - Center for research of Fashion and Clothing - University of Zagreb / Croatia (j) JANE MALCOLM-DAVIES Fashion / UK JENNIFER POAGE London College of Fashion / UK JENNY GILBERT De Montfort University / UK JESSICA BUGG RMIT University / UK JESSICA SWEIDAN Synchronicity Earth / UK JOANA MONTEIRO London College of Fashion / UK JOANNE MATTHEWS London College Of Fashion / UK JOHANA OEH MANN Nottingham Trent University \& UKJORGE DEL RIO Universidad Nava TTHEWS JOSÉ ALEXANDRE OLIVEIRA Riopele / Portugal JOSE TEUNISSEN London College of Fashion / UK JULLA CREW L London Collegae of Fashion / UK JULIA KAROLINA FREY London College of Eashion / UK JULLANA SISSONS Nottingham Trent University /UK JULIE CULLEN UNILEVER UK / UK JULIE KIELLAND Copenhagen School of Design \& Technology / Denmark JULIET KINDERSLEY Neals Yard Remedies I UK JURE PURGAJ University of Teacher Education of Viena / Austria (k) KAREN MARIE HASLING Design School Kolding / Denmark KAROLINE THILO Copenhagen School of Design \& Technology / Denmark KATALIN MEDVEDEV University of Georgia / USA KATARZYNA KOT London College of Fashion-/UK KATE GOLDSWORTHY Chelsea College of Arts / UK KATELYN TOTH-FEJEL London College of Fashion / UK KATHERINE POGSON London College of Fashion / UK KATHERINE TOWNSEND Nottingham Trent University / UK KATY BARKER London College of Fashion / UK KAZUYA KAWASAKI Keio University SFC / Japan KELLY DEARSLEY London College of Fashion UK KIRSI NIINIMÄKI Aalto University / Finland KIRSTEN SCOTT Istituto Marangoni / UK KOTARO SANO Keio University / Japan KRISTOF AVRAMSSON Carleton University / Canada KUMKUM BHATTACHARYA London College of Fashion / UK KYE SHIMIZU Keio University / Japan KYUNGEUN SUNG De Montfort University / UK (I) LAETITIA FORST London College of Fashion / UK LAURA SANTAMARIA Sublime Mag / UK LAUREN NEILSON Common Objective UK LEA VENE CIMO - Center for Research of Fashion and Clothing - University of Zagreb / Croatia LESLEY CAMPBELL Northumbria University / UK LIGIA BARCELLOS Universidade do Minho / Porfugal LILYAN BERLIM Universidade Veiga de Almeida, ESPM / BrazI LISBETH BERG London College of Fashion / UK LIZ CIOKALLO SQUIRE London College of Fashion / UK LUCY ORTA London College of Fashion / UK LUIS ANDRE PRADO Universitade de São Paulo / Brazil LYUBOV SACHKOVA London College of Communication / UK (in) MADALENA PEREIRA Universidade da Beira Interior / Portugal MANUEL SANTOS SILVA Universidade da Beira Interior / Portuga MARCIA BERGMANN Ponficia Univorsidia Collica do RIO de Janeiro/ Brazil MARIA ALVAREZ DE TOLEDO London College of Fashion / UK MARIA ASUNCIÓN GAJITOS Hanken School of Economies / Finland MARIA BEATRIZ FERREIRA Universidade do Minho Portugal MARIA FLORES London College of Fashion / UK MARIA GOMES Fast Forward Innovation / Portugal MARIANA SILVA London College of Fashion / UK MARILENA SIAMPTANI London College of Fashion UK MARION REAL Chelsea College of Fashion / UK MARTA TORREGROSA Universidad Navarra / SPain MARYLIN DELONG University Of MinnesOta / USA MARYSSA COOK-OBREGON Londo College Of Fashion/ UK MATHLDA THAM GOldsmith Universily/ UK MATLDAASPINALL London College of Fashion / UK MATTHIEU LANNEGRAND Rive Gauche/ Russia MAUD PIROLA Creative Industries Project - Metropole of Lyon / France MD REJAUL HASAN Nort Carolina State University / USA MEGAN BOLOTN London College of Fashion / UK MEGHA CHAUHAN London College of Fashion / UK MIOULL COSTA Valenis - Texteis SA/ Polugal MILADA BURCIKOVA University or Huddersfild/ UK MINAJUGOVIC London College of Fashion / UK MIRANDA SMITHERAM Auckland University of Technology / New Zealand MIRIAM COUDOUX Swarovski / UK MOLSHREE VAID Independent profossional / india MONICA BUCHAN-NG London College of Fashion / UK MONIKA HOLGAR Queensland University of Technology / Australlia (II) NADINE MÖLLENKAMP Design School Kolding / Denmark NAOM

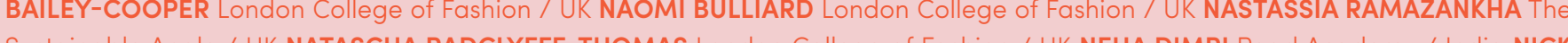
Sustainable Angle / UK NATASCHA RADCLYFFE-THOMAS London College of Fashion / UK NEHA DIMRI Pearl Academy / India NICK BRYAN-KINNS Queen Mary University of LOndon/ UK NIKI TAYLOR The Top Project/Schuh / UK NINA MARENZI The Sustainable Angle UK NINA STEVENSON London College of Fashion/, UK NOORIN KHAMISANI London College of Fashion / UK (U) OCTAVIA SA Independent professional / Portugal OLIMPIA FERNANDES Fast Forward Innovation / Portugal OLIVIA WEBER London College of Fashion / UK OLLIE FULONG London College of Fashion / UK (ק) PAMLLA BATTY Burberry / UK PATRICIAAZAMBUJA Universidade do Minho/ Portugal PATRICIA SANMIGUEL ISEM / SPain PAUL YUILLE London College of Fashion / UK PAULA GARGOLES ISEM / Spain EK PETRA HOSE CHRSTENSEN Copenhagen School of Design a Technology/ Denmark PETER KINDERSLEY Neals Yard Remedies V

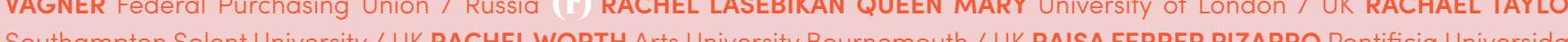
Southampion Solent University) UK RACHEL WORTH ARIs University BournemOuth UK RAISAFERRER PIZARRO POntificia Universidad UK REBECCA EARLEY Chelsea College of Arts / UK REBECCA MUNRO London College of Fashion / UK REBEKAH MATHENY The Ohio State University / USA RENEE CUOCO Rejina Pyo / UK RHIAN SOLOMON London College of Fashion / UK RIANNA FORSKITT The University of Sheffield / UK RITA SOUSA I\&D Riopele / Portugal ROSEMARY VARLEY London College of Fashion UK RUCHIRA JOSHI ASOS / UK RUI MIGUEL Universidade da Beira Interior / Portugal RUPERT WALDRON London College of Fashion / UK RUTH GLASSPOOL Routledge Taylor \& Francis / UK (S) SABRA AL-FAHAD College of Basic Education / Kuwait SAIDA BRUCE London College of Fashion / UK SANDRA GONZA Fair Wear Foundation / Netherlands SANDRA SVENSSON London College of Fashion / UK SANTOSH TARAI National Institute of Fashion Technology / India SARA CAVAGNERO Italian Red Cross / Italy SARA CHONG KWAN London College of Fashion / UK SARA LOPPO Mastra-sa / Italy SARAH JAMESON Wyoming Studios / UK SARAH PEILLON Creative Industries Project Metropole of Lyon / France SAROJINI NALLATHAMBY London College of Fashion / UK SHALINI BISHT Pearl Academy India SIMONE FINCH Queensland University / Australia SOFIE EDVARD Copenhagen School of Design \& Technology / Denmark STELLA CLAXTON Nottingham Trent University / UK SUE THOMAS Heriot Watt University / UK SVETLANA VAGNER Federal Purchasing Union / Russia SWIKRUTI PRADHAN Rustic Hue / India ( $t$ ) TAHANI ALAJAII Princess Nourah bint Abdulrahman University / Saudi Arabia TAMSIN LEJURNE Common Objective / UK TAMZIN ROLLASON RMIT University / Australia TANVEER AHMED The Open University / UK TARA MOONEY University of Wolverhampton / UK TERESA SÁDABA ISEM / Spain TERESA TRINDADE Fast Forward Innovation / Portugal TESSA MAFFUCCI Pratt Institute / USA TIBBE SMITH LARSEN Lund University / Denmark TIMO RISSANEN Parsons School of Design / USA TOBY SLADE Keio University/Bunka Gakuen University / Japan (II) ULLA RAEBILD Design School Kolding / Denmark (V) VIBEKE RIISBERG Design School Kolding / Denmark (W) WASMIYAH ALAQL Princess Nourah bint Abdulrahman University / Saudi Arabia WOUTER EGGINK University of Twente / Netherlands ( $\mathrm{x}$ ) XIN ZHANG Birmingham City University / UK (y) YANINA AUBREY London College of Fashion / UK YASUHIRO OTA Tokuyama University - Shunan / Japan YIJING GAO London College of Fashion / UK (Z) ZOE NORTON London College of Fashion / UK 


\section{Conference Map}

LONDON COLLEGE OF FASHION

5
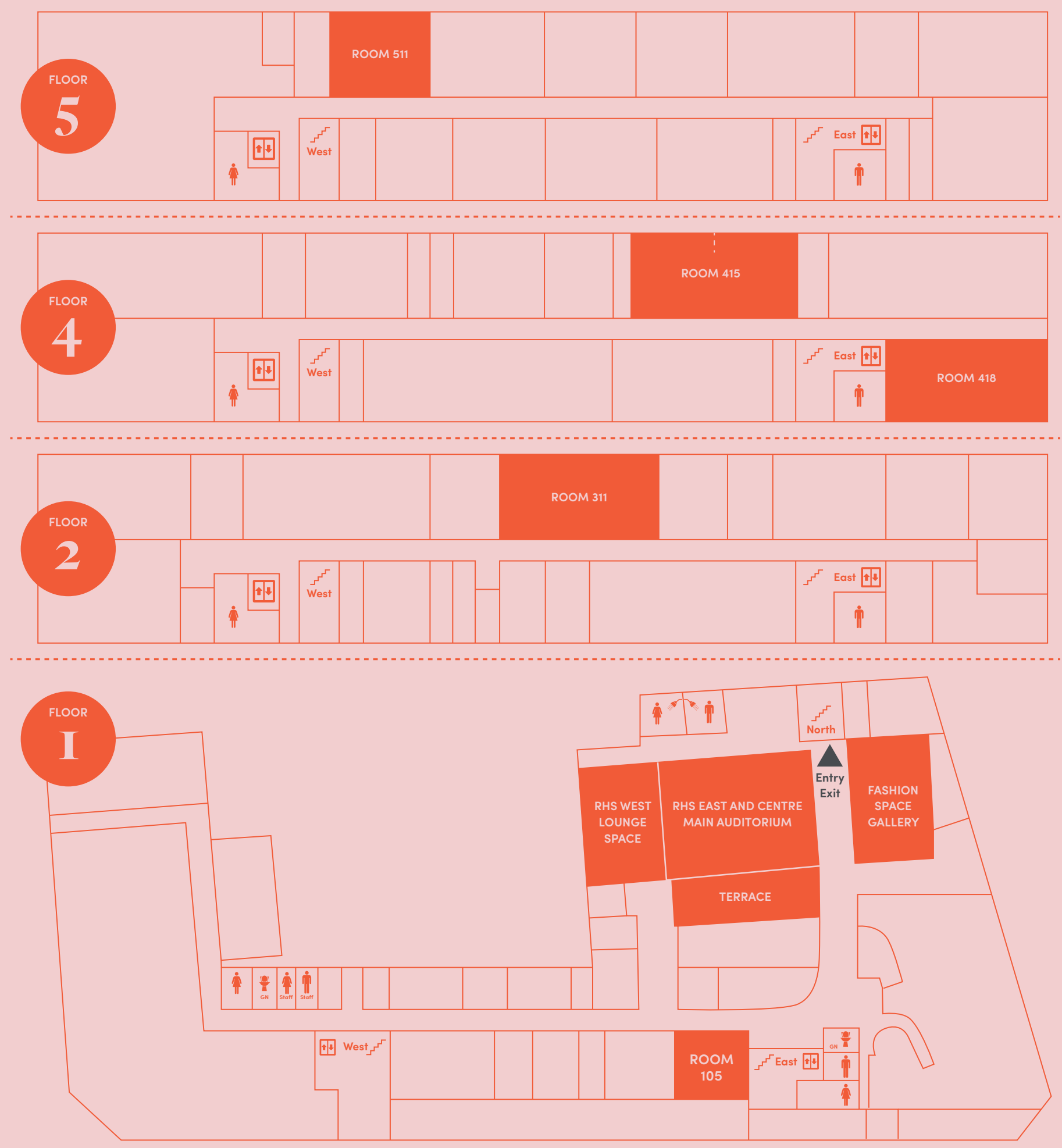

fashion design sustainability research education partnership transformation ideas debate hope 